\title{
FUNGSI DPRD DALAM MEWUJUDKAN GOOD GOVERNANCE
}

\author{
Jhony Fredy Hahury \\ Email: jhony_fredyhahury@yahoo.com \\ Fakultas Ilmu Sosial dan Ilmu Politik Universitas Kapuas
}

\begin{abstract}
Abstrak :Dewan Perwakilan Rakyat Daerah (DPRD) lembaga perwakilan rakyat di daerah mempunyai peran penting dalam tata kelola pemerintahan di daerah. Anggota DPRD melalui partai politik, mewakili masyarakat berperan besar dalam mengupayakan pembangunan demokrasi dan mewujudkan tata pemerintahan yang baik dan efisien di daerahnya. Upaya tersebut dilakukan dengan mengoptimalkan fungsi-fungsi DPRD yaitu: legislasi, penganggaran, dan pengawasan. Untuk mencapai kinerja yang maksimal dalam pelaksanaan fungsi-fungsi tersebut, perlu dilakukan penguatan terhadap kapasitas DPRD.Keberadaan DPRD sangat penting dan strategis dalam melaksanakan perannya guna mewujudkan pemerintahan yang baik dan bersih dalam menjalankan fungsinya perlu mengedepankan komitmen moral dan profesionalitas. Komitmen menjadi penting sebagai upaya untuk mewujudkan DPRD yang produktif, kredibel, dan berwibawa. Dengan demikian, fungsi DPRD dapat terwujud apabila dilaksanakan dengan mengedepankan prinsip demokrasi dan prinsip-prinsip good governance.
\end{abstract}

Kata kunci : Fungsi DPRD, Good Governance

Dewan Perwakilan Rakyat Daerah (DPRD) sebagai lembaga perwakilan rakyat, secara konseptual memegang tiga peran.Pertama, sebagai agen perumus agenda bagi masyarakat yang diwakilinya.Kedua, DPRD berperan sebagai lembaga yang mengemban misi pengelolaan konflik dalam masyarakatnya.Ketiga, DPRD adalah pengemban peran integratif dalam masyarakatnya.Peran perwakilan rakyat yang diemban oleh DPRD bisa dimaknai sebagai peran keperantaraan.DPRD bukan hanya menjadi perantara yang menjembatani pemerintah (eksekutif) dengan rakyatnya, namun juga menjembatani ketegangan dari berbagai segmen dalam masyarakat yang saling memperjuangkan kepentingannya. Dalam praktik kehidupan demokrasi DPRD sebagai lembaga legislatif memiliki posisi sentral yang dipandang terpercaya untuk membawakan aspirasi masyarakat di dalam pemerintahan. Hal ini didasarkan pada suatu pandangan bahwa badan legislatif yang dapat mewakili rakyat dan memiliki kompetensi untuk memenuhi kehendak rakyat. DPRD yang memegang peranan penting dalam sistem demokrasi paling berperan dalam proses kehidupan demokratisasi di daerah. Walaupun dalam kenyataannya DPRD masih belum sepenuhnya menjalankan fungsinya dengan baik, bahkan dalam prakteknya DPRD sering mengaburkan makna demokrasi itu sendiri.

Berdasarkan Undang-Undang Nomor 32 Tahun 2004 Pasal 41 DPRD memiliki tiga fungsi utama dalam menjalankan tugasnya yakni fungsi legislasi, fungsi pengawasan dan fungsi anggaran.
Implementasi dari ketiga fungsi itu selanjutnya dioperasionalkan dalam bentuk hak dan kewajiban anggota dalam lembaga DPRD yang kesemuanya harus di atur jelas dalam peraturan tata tertib DPRD. Pelaksanaan hak dan kewajiban sebagai manifestasi dari trifungsinya itu harus dapat dipertanggungjawabkan pada diri sendiri, masyarakat, lingkungan dan terutama konstituen yang memberikan kepercayaan penuh padanya untuk memperbaiki sistem pemerintah ke arah yang diinginkan seluruh elemen bangsa dan negara.

Lembaga legislatif sebagai lembaga perwakilan dalam bertindak atas nama kepentingan rakyat yang diwakili sebagai pencerminan demokrasi, agar dapat berjalan, lembaga legislatif memiliki beberapa macam fungsi. Berjalannya fungsi lembaga perwakilan rakyat akan dapat mencerminkan derajat demokrasi. Pada umumnya fungsi perwakilan dibedakan menjadi empat macam fungsi, yaitu (1) fungsi penganggaran, (2) fungsi perundangan, (3) fungsi pengawasan, dan (4) fungsi menampung dan menyalurkan aspirasi rakyat (Widodo, 2001:106). DPRD harus melaksanakan fungsinya dengan baik guna mewujudkan pemerintahan yang baik dan bersih yaitu dengan terselenggaranya good governance yang merupakan prasyarat utama mewujudkan aspirasi masyarakat mencapai tujuan dan citacita bangsa dan negara. Supaya pelaksanaan fungsi DPRD dapat terwujud maka pemerintahan dilaksanakan dengan mengedepankan prinsip demokrasi dan prinsipprinsip good governance. DPRD merupakan 
lembaga legislatif yang para anggotanya terpilih melalui mekanisme Pemilihan Umum. Keberadaannya (DPRD) sangat penting dan strategis dalam melaksanakan perannya guna mewujudkan pemerintahan yang baik dan bersih (good and clean governance) dalam menjalankan fungsinya perlu mengedepankan komitmen moral dan profesionalitas. Komitmen menjadi penting sebagai upaya untuk mewujudkan DPRD yang produktif, terpercaya dan berwibawa.

Sejalan dengan perkembangan politik pemerintahan dari waktu ke waktu mengalami sebuah pergeseran paradigma sistem penyelenggaraan pemerintahan dari sistem pemerintahan yang bercorak sentralisasi menjadi sistem pemerintahan desentralisasi. Hal ini juga berpengaruh pada fungsi DPRD Kota Malang sebagai legislatif daerah yang menjadi pilar penting dalam mewujudkan pemerintahan yang baik serta dapat meningkatkan kesejahteraan masyarakat melalui pelayanan publik yang prima. Oleh karena itu, DPRD Kota Malang dari sisi pelaksanaan fungsinya yang belum optimal jika mengacu pada fungsi pengawasan, aspirasi, dan fungsi legislasi. Secara konseptual kebijakan publik dapat dilihat dari Kamus Administrasi Publik Chandler dan Plano (dalam Pasolong,2007:38), mengatakan bahwa kebijakan publik adalah pemanfaatan yang strategis terhadap sumber-sumber daya yang ada untuk memecahkan masalah publik atau pemerintah. Bahkan Chandler dan Plano beranggapan bahwa kebijakan publik merupakan suatu bentuk investasi yang kontinu oleh pemerintah demi kepentingan orang-orang yang tidak berdaya dalam mayarakat agar mereka dapat hidup dan ikut berpartisipasi dalam pemerintahan. Menurut Dye (dalam Widodo, 2001:189) mengartikan"public policy is whatever governments choose to do or not to do" (kebijakan publik adalah apapun yang dipilih oleh pemerintah untuk dilakukan atau tidak dilakukan). Implikasi dari pengertian kebijakan publik dapat di uraikan, yakni (1) bahwa kebijakan itu selalu mempunyai tujuan tertentu atau merupakan suatu tindakan yang berorientasi tujuan, (2) bahwa kebijaksanaan itu berisi tindakan-tindakan atau pola tindakan pemerintah, (3) bahwa kebijaksanaan itu merupakan apa yang benar-benar dilakukan oleh pemerintah, (4) bahwa kebijaksanaan itu berdasarkan pada peraturan atau perundangundangan yang bersifat memaksa (Ekowati, 2009:5).

Oleh karena itu, untuk mengetahui kinerja kebijakan maka dibutuhkan evaluasi kebijakan. Sehingga, evaluasi kebijakan publik merupakan suatu proses untuk menilai seberapa jauh suatu kebijakan publik dapat "membuahkan hasil", yaitu dengan membandingkan antara hasil yang diperoleh dengan tujuan dan atau target kebijakan publik yang ditentukan. Evaluasi kebijakan publik tidak hanya untuk melihat hasil (outcomes) atau dampak (impacts), akan tetapi dapat pula melihat bagaimana proses implementasi suatu kebijakan. Dengan kata lain evaluasi dapat pula digunakan untuk melihat apakah proses pelaksanaan suatu kebijakan telah dilaksanakan sesuai dengan petunjuk teknis/ pelaksanaan (guide lines) yang telah ditentukan (Widodo, 2006: 112).

Selanjutnya menurut Dunn (2000) term evaluasi mempunyai arti yang berhubungan, masingmasing menunjukkan pada aplikasi beberapa skala nilai terhadap hasil kebijakan dan program. Secara umum istilah evaluasi dapat disamakan dengan penaksiran (appraisal), pemberian angka (ratting), dan penilaian (assessment), kata-kata yang menyatakan usaha untuk menganalisis hasil kebijakan dalam arti satuan nilainya. Dalam arti yang lebih spesifik, evaluasi berkenaan dengan produksi informasi mengenai nilai atau manfaat hasil kebijakan. Ketika hasil kebijakan pada kenyataannya mempunyai nilai, hal ini karena hasil tersebut memberi sumbangan pada tujuan atau sasaran. Sehingga dikatakan bahwa kebijakan atau program telah mencapai tingkat kinerja yang bermakna, yang berarti bahwa masalah-masalah kebijakan dibuat jelas atau diatasi (Sadhana, 2011:243). Oleh karena itu, evaluasi kebijakan dapat dikatakan sebagai kegiatan yang menyangkut estimasi atau penilaian kebijakan yang mencakup substansi, implementasi dan dampak. Dalam hal ini, evaluasi kebijakan dipandang sebagai suatu kegiatan fungsional. Artinya, evaluasi kebijakan tidak hanya dilakukan pada tahap akhir saja, melainkan dilakukan dalam seluruh proses kebijakan. Dengan demikian, evaluasi kebijakan bisa meliputi tahap perumusan masalah-masalah kebijakan, programprogram yang diusulkan untuk menyelesaikan masalah kebijakan, implementasi, maupun tahap dampak kebijakan.

Di samping itu, di dalam melakukan evaluasi kebijakan ada kendala yang bisa menghambat evaluasi kebijakan. Sebagaimana dikatakan oleh Nawawi (2007:166-167) bahwa ada beberapa kendala dalam evaluasi kebijakan, antara lain : Kendala psikologis. Banyak aparat pemerintah masih alergi terhadap kegiatan evaluasi, karena dipandang berkaitan dengan dirinya; Kendala ekonomis. Harus ada dukungan financial; Kendala teknis. Evaluator kebanyakan dihadapkan pada maslah tidak tersedianya cukup data informasi yang up to date; Kendala politis. Evaluasi sering terbentur bahkan gagal karena alasan politis, masing-masing kelp bisa jadi saling menutupi kelemahan dari implementasi suatu program dikarenakan ada deal atau bargaining politik tertentu; Kurang tersedianya evaluator. Pada berbagai lembaga pemerintah kurang tersedianya SDM yg memiliki kompetensi melakukakn evaluasi. 
Berkaitan dengan perumus kebijakan, maka lembaga legislative khususnya DPRD yang merupakan tugas sebagai pembuat kebijakan politik daerah.Lembaga legislatif merupakan sarana untuk melaksanakan mekanisme politik yang demokratis, dimana rakyat mempengaruhi setiap proses pembuatan keputusan politik melalui wakil-wakilnya yang duduk di lembaga legislatif. Dengan demikian, setiap kebijakan yang muncul sebagai hasil keputusan politik, secara politis merupakan kehendak rakyat atau manifestasi dari tuntutan dan kepentingan rakyat. Menurut Budiardjo (1993:261) mendefinisikan badan legislatif adalah badan yang tugas utamanya adalah di bidang perundang-undangan, menentukan kebijakan (policy), membuat Undang-Undang termasuk mengadakan amandemen terhadap rancangan Undang-Undang yang diajukan oleh oleh pemerintah, hak budget serta mengontrol badan eksekutif agar semua tindakannya sesuai dengan kebijaksanaan yang telah ditentukan Sehingga dapat disimpulkan bahwa lembaga atau badan legislatif adalah lembaga yang mempunyai kewenangan dalam hal pembuatan peraturan perundang-undangan sebagai perwujudan dari kehendak rakyat.

Berdasarkan Undang-Undang Dasar 1945, lembaga legislatif yang ada di Indonesia meliputi DPR, DPRD Propinsi dan DPRD Kabupaten dan Kota (Mashudi, 1993:17). Akan tetapi, dalam praktiknya lembaga legislatif yang melaksanakan fungsi legislasi yakni membuat Undang-Undang di Indonesia adalah DPR dan DPRD sedangkan MPR merupakan lembaga konstitutif yakni lembaga yang berfungsi membuat konstitusi (UUD).

DPR dan DPRD pada dasarnya mempunyai kedudukan, tugas, hak wewenang, dan kewajiban yang sama dalam struktur pemerintahan. Perbedaannya terletak pada wilayah yurisdiksinya, dimana DPR merupakan lembaga legislatif di tingkat pusat sedangkan DPRD di tingkat daerah. Dengan demikian lingkup perwakilannya pun berbeda, DPR seharusnya mencerminkan kekuatan dan kepentingan politik nasional serta DPRD mencerminkan konfigurasi dan kepentingan politik daerah. Penjelasan Undang-Undang Nomor 32 Tahun 2004 tentang Pemerintahan Daerah menyebutkan bahwa DPRD merupakan lembaga perwakilan rakyat daerah dan berkedudukan sebagai unsur penyelenggaraan pemerintahan daerah. Berbeda dengan Undang-Undang No. 22 tahun 1999 yang menyebutkan bahwa susunan pemerintahan daerah otonom meliputi DPRD dan Pemerintahan Daerah dan dalam penjelasan undang-undang terdapat pemisahan yang tegas antara legislatif dan eksekutif. DPRD sebagai lembaga perwakilan rakyat di daerah merupakan wahana untuk melaksanakan demokrasi dan sebagai badan legislatif daerah, DPRD berkedudukan sebagai unsur penyelenggaraan pemerintahan daerah (Pasal 40). Kedudukannya sebagai unsur penyelenggaraan pemerintahan daerah dimaksudkan untuk terciptanya hubungan kerja yang harmonis dan mewujudkan pemerintahan yang berdaya guna dan berhasil guna, demokratis, dan terpercaya (Koswara, 2005:42).

Dengan demikian, DPRD memiliki fungsi utama yaitu, (1) fungsi legislasi diwujudkan dalam membentuk peraturan daerah bersama bupati, (2) fungsi anggaran, menyusun dan menetapkan APBD bersama pemerintah daerah, dan (3) fungsi pengawasan, diwujudkan dalam bentuk pengawasan terhadap pelaksanaan Undang-Undang, peraturan daerah, keputusan Bupati, dan kebijakan yang ditetapkan oleh pemerintah daerah. Penyelenggaraan pemerintahan diharapkan agar mampu mewujudkan pemerintahan yang professional, adil, terbuka dan bebas dari korupsi, klusi, dan nepotisme (KKN) sesuai dengan konsep good governance.Secara konseptual pengertian good dalam istilah good governance menurut LAN (2000) dalam Widodo (2001:23) mengandung dua pengertian.Pertama, nilai yang menjunjung tinggi keinginan atau kehendak rakyat, dan nilai-nilai yang dapat meningkatkan kemampuan rakyat dalam pencapaian tujuan nasional kemandirian, pembangunan berkelanjutan dan keadilan sosial.Kedua, aspek fungsional dari pemerintahan yang efektif dan efisien dalam pelaksanaan tugasnya untuk mencapai tujuan-tujuan tersebut.

Good governance menurut Bank Dunia (world bank) ialah suatu penyelenggaraan manajemen pembangunan yang solid dan bertanggungjawab yang sejalan dengan prinsip demokrasi dan pasar yang efisien, penghindaran terhadap kemungkinan salah alokasi dan investasi, dan pencegahan korupsi baik yang secara politik maupun administratif, menjalankan disiplin anggaran serta penciptaan legal dan political framework bagi tumbuhnya aktivitas usaha (Mardiasmo, 2002 : 23). Sementara itu United Nations Development Program (UNDP) dalam dokumen kebijakannya yang berjudul "Governance for sustainable human development”, (1997), mendefinisikan kepemerintahan(governance) adalah pelaksanaan kewenangan atau kekuasaan di bidang ekonomi, politik dan 
administratif untuk mengelola berbagai urusan negara pada setiap tingkatannya dan merupakan instrumen kebijakan negara untuk mendorong terciptanya kondisi kesejahteraan integritas, dan kohesivitas sosial dalam masyarakat.UNDPjuga mendefinisikan good governance sebagai hubungan yang sinergis dan konstruktif di antara negara, sektor swasta dan masyarakat.

Menurut UNDP (1997) dalam Widodo (2001:25) mengajukan karakteristik atau prinsip pada pelaksanaan good governance sebagai berikut:

1. Participation. Setiap warga negara mempunyai suara dalam pembuatan keputusan baik secara langsung maupun intermediasi institusi legitimasi yang mewakilinya. Partisipasi seperti ini dibangun atas dasar kebebasan berasosiasi dan berbicara serta berpartisipasi secara konstruktif.

2. Rule of law. Kerangka hukum harus adil dan dilaksanakan secara utuh, terutama hukum tentang hak asasi manusia.

3. Transparency. Transparansi dibangun atas dasar kebebasan memperoleh informasi. Informasi yang berkaitan dengan kepentingan publik secara langsung dapat diperoleh oleh mereka yang membutuhkan. Informasi harus dapat dipahami dan dapat di monitor.

4. Responsivennes. Lembaga-lembaga dan proses-proses harus mencoba untuk melayani berbagai pihak yang berkepentingan (stakeholders).

5. Consensus Orientation. Good governance menjadi perantara kepentingan yang berbeda untuk memperoleh pilihan-pilihan terbaik bagi kepentingan yang lebih luas baik dalam hal kebijakan-kebijakan maupun prosedur-prosedur.

6. Equity. setiap masyarakat memiliki kesempatan sama untuk memperoleh kesejahteraan dan keadilan.

7. Efficiency and Effectivennes. Setiap proses kegiatan dan kelembagaan diarahkan untuk menghasilkan sesuatu yang benar-benar sesuai dengan kebutuhan melalui pemanfaatan yang sebaik-baiknya berbagai sumber-sumber yang tersedia serta pengelolaan sumber daya publik dilakukan secara berdaya guna (efisien) dan berhasil guna (efektif).

8. Accountability. Para pembuat keputusan dalam pemerintahan, sektor swasta, dan masyarakat (civil society) bertanggung jawab kepada publik dan lembaga-lembaga "stakeholders". Akuntabiltas ini tergantung pada organisasi dan sifat keputusan yang dibuat, apakah keputusan tersebut untuk kepentingan internal atau eksternal organisasi.

9. Strategic Vision. Para pemimpin dan publik harus mempunyai perspektif good governance dan pengembangan manusia yang luas dan jauh ke depan sejalan dengan apa yang diperlukan untuk pembangunan tersebut.

\section{METODE PENELITIAN}

Penelitian ini dilaksanakan Pada Dewan Perwakilan Rakyat Daerah (DPRD) Kota Malang yang beralamat di Jl. Tugu No. 1A Kota Malang Jawa Timur. Penelitian ini menggunakan jenis penelitian kualitatif. Informan dalam penelitian dengan menggunakan purposive sampling. Purposive sampling ini dengan kecenderungan peneliti untuk memilih informan yang dianggap mengetahui informasi masalah secara mendalam dan dapat dipercaya untuk menjadi sumber data yang benar (Sutopo, 2002:56). Data dikumpulkan melalui teknik observasi, dokumentasi, dan kuesioner (angket).Analisis data yang digunakan dalam penelitian ini dengan jenis data yang ditampilkan adalah dari kuesioner atau data primer dimana data hanya didapat langsung dari responden dan masih dalam keadaan mentah. Oleh karena itu, perlu diolah agar dapat memberikan arti dalam menyimpulkan masalah penelitian.

\section{HASIL DAN PEMBAHASAN}

Dewan Perwakilan Rakyat Daerah (DPRD) Kota Malang merupakan lembaga politik daerah yang menampung yang memiliki fungsi aspirasi masyarakat dalam meningkatkan pembangunan dan kesejahteraan masyarakat Kota Malang. Visi DPRD Kota Malang Periode 20092014 adalah "Tercapainya aparatur politis yang kualitatif, aspiratif, dan prospektif terhadap kemajuan dan kesejahteraan masyarakat Kota Malang”. Sedangkan misinya adalah Mewujudkan anggota DPRD yang berwawasan luas, memiliki kemampuan dan integritas yang tinggi. Mewujudkan DPRD sebagai lembaga perwakilan rakyat yang responsif, solutif, dan aplikatif. Mewujudkan peran publik DPRD terhadap kemajuan dan perkembangan serta kesejahteraan masyarakat Kota Malang. DPRD terdiri atas anggota partai politik peserta pemilihan umum yang dipilih melalui Pemilihan Umum Tahun 2009. Alat kelengkapan DPRD Kota Malang menurut Peraturan DPRD Kota Malang No. 01 Tahun 2011 tentang Tata Tertib DPRD Kota Malang terdiri dari Pasal 39:

1). Alat kelengkapan terdiri atas :

a. Pimpinan;

b. Badan Musyawarah;

c. Komisi;

d. Badan Legislasi Daerah;

e. Badan Anggaran,

f. Badan Kehormatan,

g. Alat kelengkapan lain yang diperlukan dan dibentuk oleh rapat paripurna. 
2). Kepemimpinan alat kelengkapan DPRD sebagaimana dimaksud pada ayat (1) bersifat kolektif kolegial.

3). Dalam menjalankan tugasnya alat kelengkapan dibantu oleh sekretariat.

Sebagaimana Peraturan DPRD, maka Pimpinan DPRD Kota Malang terdiri atas 1 (satu) orang ketua dan 3 (tiga) orang wakil ketua. Pimpinan DPRD Kota Malang mempunyai tugas, sebagaimana Pasal 44 antara lain :

a. Memimpin sidang DPRD dan menyimpulkan hasil sidang untuk diambil keputusan;

b. Menyusun rencana kerja pimpinan dan mengadakan pembagian kerja antara ketua dan wakil ketua;

c. Melakukan koordinasi dalam upaya menyinergikan pelaksanaan, agenda dan materi kegiatan dari alat kelengkapan DPRD;

d. Menjadi juru bicara DPRD;

e. Menandatangi surat-surat dinas DPRD;

f. Melaksanakan dan memasyarakatkan keputusan DPRD;

g. Mewakili DPRD dalam berhubungan dengan lembaga/instansi lainnya;

h. Mengadakan konsultasi dengan kepala daerah dan pimpinan lembaga/instansi lainnya sesuai dengan keputusan DPRD;

i. Mewakili DPRD di pengadilan;

j. Melaksanakan keputusan DPRD berkenaan dengan penetapan sanksi atau rehabilitasi anggota sesuai dengan ketentuan peraturan perundang-undangan;

k. Menyusun rencana anggaran DPRD bersama Sekretariat DPRD yang pengesahannya dilakukan dalam rapat paripurna;

1. Menyampaikan laporan kinerja pimpinan DPRD dalam rapat paripurna DPRD yang khusus diadakan untuk itu.

Badan Musyawarah mempunyai tugas, Pasal 50 yakni :

a. Menetapkan agenda DPRD untuk 1 (satu) tahun sidang, 1 (satu) masa persidangan, atau sebagian dari suatu masa sidang, perkiraan waktu penyelesaian suatu masalah, dan jangka waktu penyelesaian rancangan peraturan daerah, dengan tidak mengurangi kewenangan rapat paripurna untuk mengubahnya;

b. Memberikan pendapat kepada pimpinan DPRD dalam menentukan garis kebijakan yang menyangkut pelaksanaan tugas dan wewenang DPRD;

c. Meminta dan/atau memberikan kesempatan kepada alat kelengkapan DPRD yang lain untuk memberikan keterangan/penjelasan mengenai pelaksanaan tugas masing-masing;

d. Menetapkan jadwal acara rapat DPRD; e. Memberi saran/pendapat untuk rnemperlancar kegiatan;

f. Merekomendasikan pembentukan panitia khusus;

g. Melaksanakan tugas lain yang diserahkan oleh rapat paripurna kepada Badan Musyawarah.

Komisi merupakan alat kelengkapan DPRD yang bersifat tetap dan dibentuk oleh DPRD pada awal masa jabatan keanggotaan DPRD. Komisi mempunyai tugas sebagaimana dalam Pasal 51, yakni :

a. Mengupayakan terlaksananya kewajiban daerah sesuai dengan ketentuan peraturan perundang-undangan;

b. Melakukan pembahasan terhadap rancangan peraturan daerah, dan rancangan keputusan DPRD;

c. Melakukan pengawasan terhadap pelaksanaan pertauran daerah dan APBD sesuai dengan ruang lingkup tugas komisi;

d. Membantu pimpinan DPRD untuk mengupayakan penyelesaian masalah yang disampaikan oleh kepala daerah dan/atau masyarakat kepada DPRD;

e. Menerima, menampung, dan membahas serta menindaklanjuti aspirasi masyarakat;

f. Memperhatikan upaya peningkatan kesejahteraan rakyat di daerah;

g. Melakukan kunjungan kerja komisi yang bersangkutan atas persetujuan pimpinan DPRD;

h. Mengadakan rapat kerja dan rapat dengar pendapat;

i. Mengajukan usul kepada pimpinan DPRD yang termasuk dalam ruang lingkup bidang tugas masing-masing komisi;

j. Memberikan laporan tertulis kepada pimpinan DPRD tentang hasil pelaksanaan tugas komisi.

DPRD Kota Malang periode 2009-2014 memiliki 4 komisi yang sesuai dengan Pasal 52 ayat (ayat 1 dan 2) antara lain :

1). Komisi-komisi DPRD terdiri dari :

a. Komisi A : Bidang Hukum dan Pemerintahan;

b. Komisi B : Bidang Perekonomian dan Keuangan;

c. Komisi C : Bidang Pembangunan;

d. Komisi D : Bidang Kesejahteraan Rakyat.

2). Ruang lingkup bidang tugas masing-masing Komisi, yaitu :

a. Komsi A Bidang Hukum dan Pemerintahan Bidang tugasnya meliputi : Pemerintahan, Kearsipan, Ketertiban, Kependudukan, Penerangan/Pers,Hukum/Perudang-undangan, Kepegawaian/Aparatur, Perizinan, Sosial Politik, Oraganisasi Masyarakat, Pertanahan, Penelitian dan Pengembangan; 
b. Komisi B Bidang Perekonomian dan Keuangan Bidang tugasnya meliputi : Perekonomian, Perindustian dan Perdagangan, Perbankan, Pertanian, Perikanan, Kelautan, Peternakan, Perkebunan, Kehutanan, Pengadaan Pangan, Logistik, Koperasi, Keuangan Daerah, Perpajakan dan Retribusi, Pemegang Kas Daerah dan Perusahaan Daerah/Badan Usaha Milik Daerah, Perusahaan Patungan, Badan Usaha dan Penanaman Modal;

c. Komisi C Bidang Pembangunan

Bidang tugasnya meliputi : Pembangunan, Pekerjaan Umum, Tata Ruang, Pertamanan dan Kebersihan, Perhubungan, Pertambangan dan Sumber Daya Mineral, Perumahan Rakyat dan Lingkungan Hidup;

d. Komisi D Bidang Kesejahteraan Rakyat Bidang tugasnya meliputi : Ketenagakerjaan, Pendidikan, Ilmu Pengetahuan dan Teknologi, Kepustakaan, Kebudayaan dan Pariwisata, Kepemudaan dan Olah Raga, Agama, Sosial, Kesehatan dan Keluarga Berencana, Peranan Wanita dan Transmigrasi.

Badan Legislasi daerah merupakan alat kelengkapan DPRD yang bersifat tetap, dibentuk dalam rapat paripurna DPRD Kota. Badan legislasi daerah DPRD Kota Malang bertugas sesuai Pasal 57, antara lain :

a. Menyusun rancangan program legislasi daerah yang memuat daftar urutan dan prioritas rancangan peraturan daerah beserta alasannya untuk setiap tahun anggaran di lingkungan DPRD;

b. Koordinasi untuk penyusunan program legislasi daerah antara DPRD dan pemerintah daerah;

c. Menyiapkan rancangan peraturan daerah usul DPRD berdasarkan program prioritas yang telah ditetapkan;

d. Melakukan pengharmonisasian, pembulatan, dan pemantapan konsepsi rancangan peraturan daerah yang diajukan anggota, komisi dan/atau gabungan komisi sebelum rancangan peraturan daerah tersebut disampaikan kepada pimpinan DPRD;

e. Memberikan pertimbangan terhadap rancangan peraturan daerah yang diajukan oleh anggota, komisi dan/atau gabungan komisi, di luar prioritas rancangan peraturan daerah tahun berjalan atau di luar rancangan peraturan daerah yang terdaftar dalam program legislasi daerah;

f. Mengikuti perkembangan dan melakukan evaluasi terhadap pembahasan materi muatan rancangan peraturan daerah melalui koordinasi dengan komisi dan/atau panitia khusus;

g. Memberikan masukan kepada pimpinan DPRD atas rancangan peraturan daerah yang ditugaskan oleh Badan Musyawarah;

h. Membuat laporan kinerja pada masa akhir keanggotaan DPRD baik yang sudah maupun yang belum terselesaikan untuk dapat digunakan sebagai bahan oleh komisi pada masa keanggotaan berikutnya.

Badan Anggaran merupakan alat kelengkapan DPRD yang bersifat tetap dan dibentuk oleh DPRD pada awal masa jabatan keanggotaan DPRD. Badan Anggaran tugasnya sebagaimana pasal 59 adalah:

a. Memberikan saran dan pendapat berupa pokokpokok pikiran DPRD kepada kepala daerah dalam mempersiapkan rancangan anggaran pendapatan dan belanja daerah paling lambat 5 (lima) bulan sebelum ditetapkannya APBD;

b. Melakukan konsultasi yang dapat diwakili oleh anggotanya kepada komisi terkait untuk memperoleh masukan dalam rangka pembahasan rancangan kebijakan umum APBD serta prioritas dan plafon anggaran sementara;

c. Memberikan saran dan pendapat kepada kepala daerah dalam mempersiapkan rancangan peraturan daerah tentang perubahan APBD dan rancangan peraturan daerah tentang pertanggungjawaban pelaksanaan APBD;

d. Melakukan penyempurnaan rancangan peraturan daerah tentang APBD dan rancangan peraturan daerah tentang pertanggungjawaban pelaksanaan APBD berdasarkan hasil evaluasi Gubernur bersama tim anggaran pemerintah daerah;

e. Melakukan pembahasan bersama tim anggaran pemerintah daerah terhadap rancangan kebijakan umum APBD serta rancangan prioritas dan plafon anggaran sementara yang disampaikan oleh kepala daerah;

f. Memberikan saran kepada pimpinan DPRD dalam penyusunan anggaran belanja DPRD.

Badan Kehormatan di bentuk oleh DPRD dan merupakan alat kelengkapan DPRD yang bersifat tetap. Badan Kehormatan mempunyai tugas sebagaimana Pasal 60 :

1). Badan Kehormatan Mempunyai tugas :

a. Memantau dan mengevaluasi disiplin dan/ atau kepatuhan terhadap moral, kode etik, dan/ atau peraturan tata tertib DPRD dalam rangka menjaga martabat, kehormatan, citra dan kredibilitas DPRD;

b. Meneliti dugaan pelanggaran yang dilakukan anggota DPRD terhadap peraturan tata tertib, dan/atau kode Etik DPRD;

c. Melakukan penyelidikan, verifikasi, dan klarifikasi atas pengaduan pimpinan DPRD, anggota DPRD, dan/atau masyarakat;

d. Melaporkan keputusan Badan Kehormatan atas hasil penyelidikan, verifikasi, dan klarifikasi sebagaimana dimaksud pada huruf (c) kepada rapat paripurna DPRD. 
2). Dalam melaksanakan penyelidikan, verifikasi, dan klarifikasi sebagaimana dimaksud pada ayat (1), Badan Kehormatan dapat meminta bantuan dari ahli independen.

DPRD merupakan lembaga perwakilan rakyat daerah yang berkedudukan sebagai unsur penyelenggara pemerintahan daerah. Berdasarkan Peraturan DPRD Kota Malang No. 01 Tahun 2011 tentang Tata Tertib DPRD Kota Malang Pasal 4 ayat 1 anggota DPRD Kota Malang 2009-2014 berjumlah sebanyak 45 (empat puluh lima) orang yang terdiri dari :

a. 12 orang anggota dari unsur Partai Demokrat;

b. 9 orang anggota dari unsur Partai Demokrasi Indonesia Perjuangan;

c. 5 orang anggota dari unsur Partai Kebangkitan Bangsa;

d. 5 orang anggota dari unsur Partai Keadilan Sejahtera;

e. 5 orang anggota dari unsur Partai Golongan Karya;

f. 4 orang anggota dari unsur Partai Amanat Nasional;

g. 2 orang anggota dari unsur Partai Gerakan Indonesia Raya;

h. 1 orang anggota dari unsur Partai Damai Sejahtera;

i. 1 orang anggota dari unsur Partai Hati Nurani Rakyat;

j. 1 orang anggota dari unsur Partai Karya Peduli Bangsa.

Sesuai dengan Pasal 10 ayat 1 Peraturan DPRD Kota Malang No. 01 Tahun 2011 tentang Tata Tertib DPRD Kota Malang. DPRD Kota Malang mempunyai tugas dan wewenang :

a. Membentuk peraturan daerah bersama kepala daerah;

b. Membahas dan memberikan persetujuan rancangan peraturan daerah mengenai APBD yang diajukan oleh kepala daerah ;

c. Melaksanakan pengawasan terhadap peraturan daerah dan APBD;

d. Mengusulkan pengangkatan dan/atau pemberhentian kepala daerah dan/atau wakil kepala daerah kepada Menteri Dalam Negeri melalui gubernur untuk mendapatkan pengesahan pengangkatan dan/atau pemberhentian;

e. Memilih wakil kepala daerah dalam hal terjadi kekosongan jabatan wakil kepala daerah; f. Memberikan pendapat dan pertimbangan kepada pemerintah daerah terhadap rencana perjanjian internasional di daerah;

g. Memberikan persetujuan terhadap rencana kerjasama internasional yang dilakukan oleh pemerintah daerah;

h. Meminta laporan keterangan pertanggungjawaban kepala daerah dalam penyelenggaraan pemerintah daerah;

i. Memberikan persetujuan terhadap rencana kerjasama dengan daerah lain atau dengan pihak ketiga yang membebani masyarakat dan daerah;

j. Mengupayakan terlaksananya kewajiban daerah sesuai dengan ketentuan peraturan perundangundangan;

k. Melaksanakan tugas dan wewenang lain yang diatur dalam ketentuan peraturan perundangundangan.

Untuk dapat melaksanakan dan mengoptimalkan fungsi, tugas dan wewenang serta hak dan kewajiban DPRD, maka dibentuklah fraksi sebagai wadah berhimpun anggota DPRD. Menurut Pasal 38 fraksi-fraksi yang terdapat di DPRD Kota Malang 2009-2014 terdiri dari :

a. Fraksi Demokrat, meliputi anggota DPRD yang mewakili Partai Demokrat;

b. Fraksi Partai Demokrasi Indonesia Perjuangan, meliputi gabungan anggota DPRD yang mewakili Partai Demokrasi Indonesia Perjuangan dan Partai Karya Peduli Bangsa;

c. Fraksi Partai Kebangkita Bangsa, meliputi anggota DPRD yang mewakili Partai Kebangkitaan Bangsa;

d. Fraksi Partai Keadilan Sejahtera, meliputi anggota DPRD yang mewakili Partai Keadilaan Sejahtera;

e. Fraksi Partai Golongan Karya, meliputi anggota DPRD yang mewakili Partai Golongan Karya;

f. Fraksi Partai Amanat Nasional, meliputi anggota DPRD yang mewakili Partai Amanat Nasional;

g. Fraksi Gerakan Nurani Damai, meliputi gabungan anggota DPRD yang mewakili, Partai Gerakan Indonesia Raya, Partai Hati Nurani Rakyat, dan Partai Damai Sejahtera.

Sebagaimana dalam Pemilu Legislatif DPRD Kota Malang Periode 2009-2014. Dengan demikian, maka hasil perolehan Pemilu legislatif DPRD Kota Malang Periode 2009-2014 dapat di lihat pada tabel di bawah ini. 
Tabel 1. Hasil Perolehan Suara Pemilu Legislatif DPRD Kota Malang Periode 2009-2014

\begin{tabular}{|c|c|c|c|c|c|c|}
\hline No & Partai Politik & $\begin{array}{c}\text { Perolehan } \\
\text { Suara }\end{array}$ & $\begin{array}{c}\text { Perolehan } \\
\text { Kursi }\end{array}$ & L & P & Jumlah \\
\hline 1 & PDIP & 65,385 & 10 & 8 & 2 & 10 \\
\hline 2 & Golkar & 24,349 & 5 & 3 & 2 & 5 \\
\hline 3 & Demokrat & 89,050 & 12 & 8 & 4 & 12 \\
\hline 4 & PKB & 35,531 & 5 & 5 & - & 5 \\
\hline 5 & PKS & 25,646 & 5 & 4 & 1 & 5 \\
\hline 6 & PAN & 16,844 & 4 & 4 & - & 4 \\
\hline 7 & GND & 42,488 & 4 & 2 & 2 & 4 \\
\hline \multicolumn{2}{|c|}{ Jumlah } & 299,293 & 45 & 34 & 11 & 45 \\
\hline
\end{tabular}

Sumber : KPUD Kota Malang 2012

Berdasarkan data di atas, perolehan suara dari partai-partai politik yang memperoleh suara terbanyak di Kota Malang di tempati oleh : 1) Partai Demokrat 89,050 suara (12 kursi), 2) PDIP 65,385 suara (10 kursi), 3) GND 42,488 suara (4 kursi), 4) PKB 35,531 suara (5 kursi ), 5) PKS 25,646 suara (5 kursi), 6) Partai Golkar 24,349 suara(5 kursi), 7) PAN 16.844 suara (4 kursi).
Berdasarkan fokus penelitian yang telah diuraikan, maka pada sub bab ini akan disajikan hasil penelitian melalui kuesioner terbuka dengan informan yang telah dipilih. Adapun hasil penelitian dapat diuraikan sebagai berikut :

Tabel 2. Karakteristik Responden Menurut Golongan Umur

\begin{tabular}{|c|c|c|c|}
\hline No & Umur & Jumlah & Prosentase \\
\hline 1 & $30-40$ & 10 & $20 \%$ \\
\hline 2 & $40-50$ & 20 & $40 \%$ \\
\hline 3 & $50-60$ & 15 & $30 \%$ \\
\hline & Jumlah & 45 & $90 \%$ \\
\hline
\end{tabular}

Sumber Data : Kuesioner diolah 2012

Berdasarkan tabel 2 dapat diketahui bahwa sebagian besar responden (anggota DPRD Kota Malang) yang berumur 40-50 tahun (40\%) sebanyak 20 orang, untuk responden yang berusia 50-60 tahun sebanyak 15 orang (30\%) dan responden yang berusia 30-40 tahun sebanyak 10 orang $(20 \%)$.

Dari uraian di atas pada tingkat karakteristik responden menurut golongan umur bisa dikatakan bahwa anggota DPRD Kota Malang didominasi oleh umur yang masih produktif. Artinya ini menunjukkan bahwa umur seperti itu memiliki semangat bekerja yang sangat tinggi sehingga akan berpengaruh dalam meningkatkan fungsi DPRD.

Dari gambaran data di atas tentang karakteristik menurut umur jika dikorelasikan dengan fungsi DPRD dalam mewujudkan good governance, tentunya faktor umur sangat mempengaruhi fungsi dan kinerja DPRD. Disamping itu, umur anggota DPRD sebagai tujuan utama dalam meningkatkan kerja-kerja institusi DPRD. Aspek terpenting dalam bekerja adalah faktor umur tentunya hal ini dapat mendukung serta menunjang pada fungsi dan kinerja DPRD kedepan. 
Tabel 3. Karakteristik Responden Menurut Tingkat Pendidikan

\begin{tabular}{|c|l|c|c|}
\hline No & \multicolumn{1}{|c|}{ Tingkat Pendidikan } & Jumlah & Prosentase \\
\hline 1 & Tamat SMA\& Sederajat & 7 & $14 \%$ \\
\hline 2 & Tamat S1/Sarjana & 22 & $44 \%$ \\
\hline 3 & Tamat S2/Magister & 11 & $22 \%$ \\
\hline 4 & Tamat S3/Doktor & 2 & $4 \%$ \\
\hline \multicolumn{2}{r|}{ Jumlah } & 45 & $80 \%$ \\
\hline
\end{tabular}

Sumber Data : Kuesioner Diolah 2012

Berdasarkan tabel di atas didapatkan hasil bahwa sebagian besar responden pada anggota DPRD Kota Malang yaitu sebanyak 7 (14\%) orang berlatar pendidikan SMU/sederajat, sebanyak 22 orang (44\% ) berpendidikan sarjana, sebanyak 11 orang $(22 \%)$ berlatar pendidikan S2/magister, sedangkan yang berlatar pendidikan S3/doktor sebanyak $2(4 \%)$ orang. Sebagaimana yang dijelaskan pada tabel di atas terkait dengan tingkat pendidikan pada DPRD Kota Malang menunjukkan bahwa didominasi oleh anggota yang berlatar pendidikan sarjana (44\%), sementara yang berpendidikan S2/magister (22\%).Hal ini dikatakan bahwa pentingnya sumberdaya manusia yang berkualitas dan profesional bagi anggota DPRD Kota Malang sudah baik.Disamping itu, pendidikan merupakan esensi dari sumberdaya manusia itu sendiri khususnya anggota DPRD. Namun demikian, tentunya sumberdaya yang berkualitas menjadi modal penting dalam peningkatan fungsi dan kinerja DPRD yang lebih baik di masa yang akan datang. Dengan Demikian, dari uraian di atas jika dikorelasikan dengan fungsi DPRD Kota Malang, aspek sumberdaya manusia yang profesional harus diikuti oleh pendidikan yang berkualitas bagi anggota DPRD, sehingga akan menghasilkan kinerja yang berkualitas pula, dimana aspek ini menjadi faktor penunjang bagi pelaksanaan peran dan fungsi DPRD yang muaranya berdampak pada kerja-kerja institusi DPRD Kota Malang menjadi lebih baik. Responden pada penelitian ini adalah anggota DPRD Kota Malang Periode 2009-2014 yang berkaitan dengan fungsi DPRD dalam mewujudkan good governance.Karakteristik responden dalam memberikan jawaban atas kuesioner yang diajukan oleh peneliti, ditampilkan dalam tabel berikut :

\section{Mekanisme dan Prosedur Fungsi DPRD Kota Malang dalam Mewujudkan Good Governance}

Pada bagian ini peneliti melakukan evaluasi tentang mekanisme dan prosedur fungsi DPRD Kota Malang dalam mewujudkan good governance. Oleh karena itu, dalam menjalankan fungsinya DPRD Kota Malang merupakan representasi dari masyarakat dalam merperjuangkan aspirasi serta sebagai wakil rakyat yang mampu mewujudkan kebutuhan dan kepentingan rakyat. Dalam hal ini yang dilakukan oleh DPRD Kota Malang dalam rangka mewujudkan good governance. Sehingga, berdasarkan data yang diteliti dilapangan dapat dilihat sebagai berikut:

Tabel 4. Hasil Kuesioner tentang Mekanisme dan Prosedur Fungsi DPRD Kota Malang dalam Mewujudkan Good Governance

\begin{tabular}{|c|c|c|c|c|c|c|}
\hline \multirow{2}{*}{ No } & \multirow{2}{*}{ Pernyataan yang Dinilai } & \multicolumn{3}{|c|}{ Nilai Jawaban } & \multirow{2}{*}{$\%$} & \multirow{2}{*}{ Nilai } \\
\hline & & 1 & 2 & 3 & & \\
\hline 1 & $\begin{array}{l}\begin{array}{l}\text { Mekanisme } \\
\text { dengan kepentingan }\end{array} \\
\text { seharusnya } \\
\text { sehangat } \\
\text { masyarakat }\end{array}$ & 20 & 23 & $\mathrm{O}$ & 82 & Baik \\
\hline 2 & 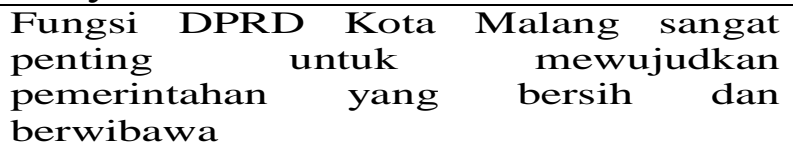 & 14 & 31 & $\mathrm{O}$ & 87 & Baik \\
\hline 3 & $\begin{array}{l}\text { Salah satu fungsi DPRD adalah fungsi } \\
\text { sebagai pengambil kebijakan publik } \\
\text { (fungsi legislasi) }\end{array}$ & 15 & 30 & $\mathbf{O}$ & 84 & Baik \\
\hline 4 & $\begin{array}{l}\text { DPRD sebagai wakil rakyat tentunya } \\
\text { lebih memperhatikan mekanisme } \\
\text { aspirasi masyarakat }\end{array}$ & 23 & 22 & O & 86 & Baik \\
\hline 5 & $\begin{array}{l}\text { Pengawasan DPRD terhadap } \\
\text { pemerintah daerah sangat penting dalam } \\
\text { mewujudkan good governance }\end{array}$ & 28 & 17 & $\mathbf{O}$ & 90 & Baik \\
\hline
\end{tabular}


Berdasarkan tabel di atas jawaban responden atas kuesioner yang diajukan mengenai mekanisme dan prosedur fungsi DPRD Kota Malang dalam mewujudkan good governance dapat dikatakan bahwa secara keseluruhan tanggapan atau persepsi dari anggota DPRD Kota Malang terhadap hal itu adalah baik. Sebab dalam melaksanakan fungsinya DPRD Kota Malang tentunya lebih mengutamakan dan melaksanakan tugas dan tanggung jawabnya dalam rangka menuju pemerintahan yang baik. Dari tabel tersebut juga terlihat bahwa tidak ada responden yang menjawab kurang setuju (3) jika dibandingkan dengan item yang lain.

Dengan demikian, disimpulkan bahwa untuk indikator mekanisme dan prosedur fungsi DPRD Kota Malang dalam mewujudkan good governance, baik itu dari segi fungsi pengawasan, pengambilan kebijakan maupun dalam konteks penjaringan aspirasi masyarakat. Persepsi atau tanggapan responden dikatakan bahwa mekanisme fungsi DPRD dalam mewujudkan good governance adalah sudah dilaksanakan dengan baik.

\section{Keterkaitan Antara Alat kelengkapan atau Badan-Badan dalam Pelaksanaan Fungsi DPRD Kota Malang}

Pada bagian ini peneliti ingin mengadakan evaluasi tentang indikator keterkaitaan antara alat kelengkapan atau badan-badan dalam pelaksanaan fungsi DPRD Kota Malang dalam mewujudkan good governance (tata kelola pemerintahan yang baik). Sehingga dapat ditampilkan tabel seperti berikut :

Tabel 5. Hasil Kuesioner tentang Keterkaitan Antara Alat kelengkapan atau Badan-Badan dalam Pelaksanaan Fungsi DPRD Kota Malang

\begin{tabular}{|l|l|c|c|c|c|c|}
\hline \multirow{2}{*}{ No } & \multicolumn{2}{|c|}{ Pernyataan yang Dinilai } & \multicolumn{2}{|c|}{ Nilai Jawaban } & \multirow{2}{*}{ Nilai } \\
\cline { 2 - 5 } & $\begin{array}{l}\text { Alat kelengkapan DPRD sebagai alat } \\
\text { untuk mencapai kinerja DPRD yang baik } \\
\text { tentunya ada hubungan komunikasi yang } \\
\text { baik }\end{array}$ & 26 & 19 & 0 & 84 & Baik \\
\hline 2 & $\begin{array}{l}\text { Komisi adalah unit kerja utama dalam } \\
\text { DPRD yang respon terhadap masalah } \\
\text { yang dihadapi oleh masyarakat }\end{array}$ & 32 & 13 & 0 & 90 & Baik \\
\hline 3 & $\begin{array}{l}\text { Badan Kehormatan sangat penting dalam } \\
\text { kinerja DPRD yang mengawasi perilaku } \\
\text { anggota DPRD }\end{array}$ & 16 & 29 & 0 & 82 & Baik \\
\hline 4 & $\begin{array}{l}\text { DPRD tidak sendiri melaksanakan } \\
\text { fungsinya tetapi ada lembaga yang } \\
\text { mendukung, pimpinan maupun komisi- } \\
\text { komisi perlu adanya kerjasama yang } \\
\text { efektif }\end{array}$ & 38 & 7 & 0 & 94 & Baik \\
\hline 5 & $\begin{array}{l}\text { Fungsi DPRD yang efektif guna } \\
\text { mewujudkan good governance maka } \\
\text { badan-badan di DPRD harus memiliki } \\
\text { visi dan misi yang sama }\end{array}$ & 28 & 0 & 80 & Baik \\
\hline
\end{tabular}

Sumber : Data Diolah 2012

Berdasarkan hasil jawaban responden pada kuesioner sebagaimana pada tabel di atas mengenai keterkaitaan antara alat kelengkapan atau badanbadan dalam pelaksanaan fungsi DPRD Kota Malang dalam mewujudkan good governance dapat dikatakan bahwa secara keseluruhan adalah baik, hal ini berkaitan dengan badan-badan yang berada dalam DPRD yang bekerja secara efektif. Salah satunya alat kelengkapan DPRD yakni komisi yang ditunjukkan dengan standar prosentase $90 \%$.
Tanggapan responden ini didasari karena hubungan alat kelengkapan DPRD Kota Malang adalah bersumber pada sistem kerja kolektif kolegial, sehingga sinergisitas antara lembaga atau badanbadan di DPRD Kota Malang dapat berjalan dengan baik. Dengan demikian, didalam menjalankan fungsi DPRD sebagaimana keterkaitan antara alat kelengkapan atau badan-badan di dalam institusi harus dijalankan secara simultan dengan proporsi yang lebih seimbang. Oleh karena itu, dalam 
menjalankan fungsi-fungsi parlemen tersebut anggota DPRD harus mampu menjaga performance dalam menyelenggarakan tugas dan tanggung jawabnya.

Faktor-Faktor yang Mendukung dan Menghambat Fungsi DPRD Kota Malang dalam Mewujudkan Good Governance

Pada bagian ini peneliti akan mengevaluasi indikator tentang faktor-faktor yang mendukung dan menghambat fungsi DPRD Kota Malang dalam mewujudkan good governance. DPRD dalam melaksanakan fungsinya sebagai wakil rakyat, sudah barang tentu tidak terlepas dari berbagai faktor yang mendukung maupun menghambat kinerja DPRD. Oleh karena itu, dalam mengevaluasi item-item tersebut tentunya harus lebih spesifik dengan mengacu pada faktor-faktor apa saja yang mendukung dan faktor-faktor penghambat dalam mewujudkan good governance. Dengan demikian, berdasarkan indikator tersebut, maka akan ditampilkan tabel sebagai berikut :

Tabel 6.Hasil Kuesioner Faktor-Faktor yang Mendukung dan Menghambat Fungsi DPRD Kota Malang dalam Mewujudkan Good Governance

\begin{tabular}{|c|l|c|c|c|c|c|}
\hline \multirow{2}{*}{ No } & \multicolumn{2}{|c|}{ Pernyataan yang Dinilai } & \multicolumn{2}{|c|}{ Nilai Jawaban } & \multirow{2}{*}{$\%$} & Nilai \\
\cline { 2 - 4 } & \multicolumn{2}{|c|}{1} & 2 & 3 & & \\
\hline 1 & $\begin{array}{l}\text { Komunikasi yang efektif dalam } \\
\text { pencapaian fungsi DPRD yang lebih } \\
\text { baik }\end{array}$ & 19 & 26 & 0 & 80 & Baik \\
\hline 2 & $\begin{array}{l}\text { Kualitas SDM (anggota) sangat penting } \\
\text { dalam mewujudkan good governance }\end{array}$ & 15 & 30 & 0 & 84 & Baik \\
\hline 3 & $\begin{array}{l}\text { Anggota DPRD kurang memperhatikan } \\
\text { aspirasi rakyat dapat menghambat } \\
\text { proses pembangunan di daerah }\end{array}$ & 12 & 33 & 0 & 90 & Baik \\
\hline 4 & $\begin{array}{l}\text { Perilaku dan sikap anggota DPRD } \\
\text { menjadi penting dalam menjaga citra } \\
\text { DPRD sebagai lembaga wakil rakyat }\end{array}$ & 24 & 21 & 0 & 86 & Baik \\
\hline 5 & $\begin{array}{l}\text { Kinerja DPRD sangat dipengaruhi oleh } \\
\text { faktor pendidikan maupun pengalaman } \\
\text { anggota DPRD }\end{array}$ & 11 & 34 & 0 & 92 & Baik \\
\hline
\end{tabular}

Sumber : Data Diolah 2012

Sebagaimana dari tabel di atas dapat dilihat hasil jawaban responden mengenai faktor-faktor yang mendukung dan menghambat fungsi DPRD Kota Malang secara keseluruhan dinyatakan baik. Persepsi yang dinilai mencakup komunikasi yang efektif, sumberdaya manusia terutama pada faktor pendidikan maupun pengalaman dinyatakan faktorfaktor tersebut merupakan faktor penunjang dan penghambat fungsi DPRD Kota Malang dalam mewujudkan good governance. Sehingga dapat disimpulkan bahwa secara keseluhan faktor-faktor penunjang dan penghambat tersebut sangat mempengaruhi fungsi DPRD Kota Malang.

Sehingga yang menjadi faktor penunjang adalah komunikasi yang efektif $(80 \%)$ serta kualitas sumberdaya anggota DPRD dengan jumlah prosentase $84 \%$. Sementara yang menjadi faktor penghambat adalah faktor pendidikan dan pengalaman (92), perilaku dan sikap anggota DPRD $(86 \%)$ dan anggota DPRD yang kurang memperhatikan aspirasi rakyat (90\%). Dengan demikian, maka faktor-faktor penghambat tersebut jika tidak diperbaiki atau benahi, tentunya hal ini sangat berpengaruh serta menghambat pencapaian fungsi dan kinerja DPRD Kota Malang.

Berdasarkan indikator yang diteliti sebagaimana menjadi parameter dalam mengevaluasi fungsi DPRD Kota Malang.Untuk masing-masing hasil jawaban responden yang berhubungan dengan fungsi DPRD Kota Malang dalam mewujudkan good governance sebagaimana dalam tampilan berikut :

Mekanisme dan Prosedur Fungsi DPRD Kota Malang dalam Mewujudkan Good Governance 


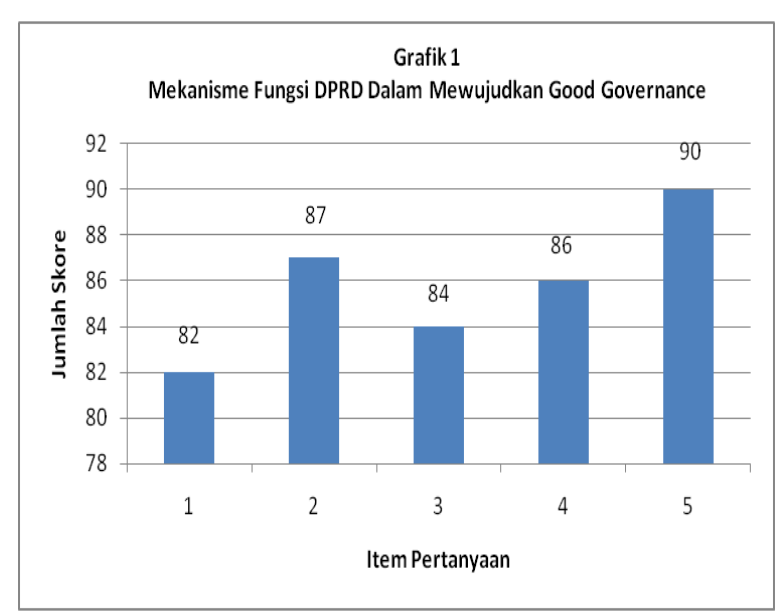

Sumber : Data Diolah 2012

Dari grafik sebagaimana di atas diketahui bahwa item pertanyaan no. 5 yaitu tentang pengawasan DPRD terhadap Pemerintah Daerah sangat penting dalam mewujudkan good governance, mencapai nilai tanggapan atau persepsi dari anggota DPRD paling tinggi jika dibandingkan dengan pertanyaan lain.Hal ini menunjukkan bahwa tingkat pengawasan DPRD sangat strategis dalam melaksanakan tugas dan tanggung jawabnya yang berhubungan dengan mekanisme pengawasan terhadap Pemerintah Daerah dalam hal ini mengenai pembangunan dan kesejahteraan masyarakat.

\section{Keterkaitan Antara Alat kelengkapan atau Badan-Badan dalam Pelaksanaan Fungsi DPRD Kota Malang}

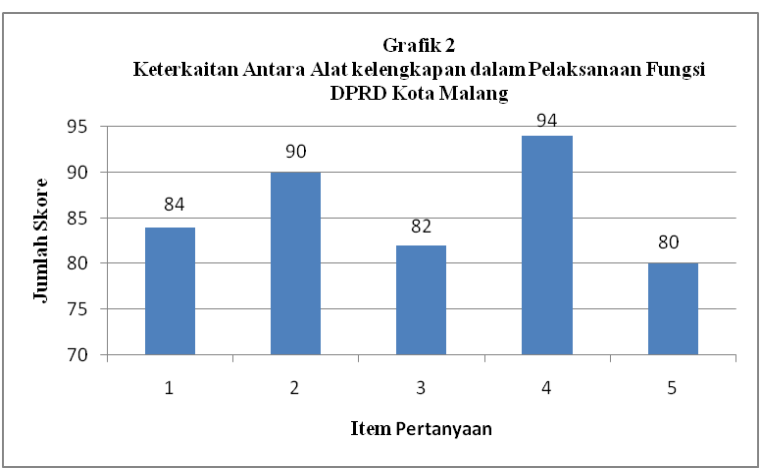

Sumber : Data Diolah 2012

Berdasarkan grafik 2 di atas, tentang tingkat keterkaitan antara alat kelengkapan DPRD dalam pelaksanaan fungsi DPRD Kota Malang tersebut di atas diketahui bahwa item pertanyaan no. 4 yaitu tentang DPRD tidak sendiri melaksanakan fungsinya tetapi ada lembaga yang mendukung, pimpinan maupun komisi-komisi perlu adanya kerjasama yang efektif, mencapai nilai tanggapan atau persepsi dari responden pada DPRD Kota Malang paling tinggi dibanding dengan item pertanyaan yang lain. Hal ini dikarenakan bahwa item tersebut merupakan pilar penting dalam mewujudkan fungsi DPRD yang lebih baik.

\section{Faktor-Faktor yang Mendukung dan Menghambat Fungsi DPRD Kota Malang dalam Mewujudkan Good Governance}

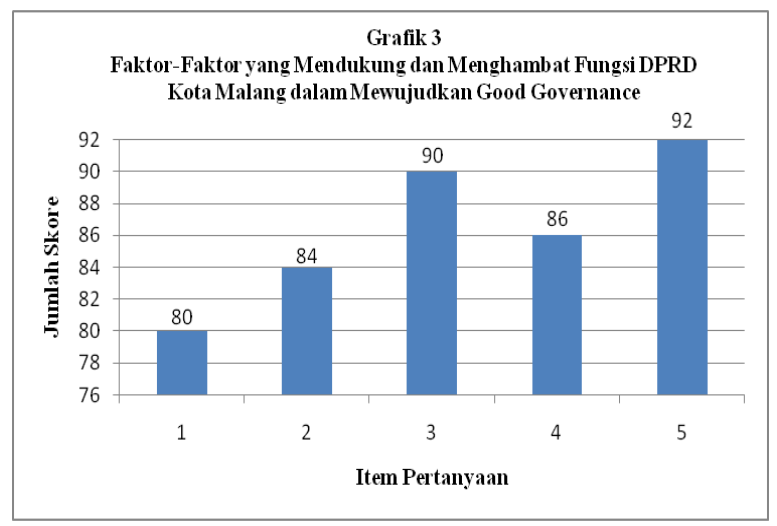

Sumber : Data Diolah 2012

Menurut grafik tentang faktor-faktor yang mendukung dan menghambat fungsi DPRD Kota Malang dalam mewujudkan good governance, dapat dikatakan bahwa item pertanyaan (no. 5) tentang kinerja DPRD sangat dipengaruhi oleh faktor pendidikan maupun pengalaman anggota DPRD. Item ini mencapai nilai tanggapan atau persepsi dengan 92 dari responden (anggota DPRD) jika dibandingkan dengan item pertanyaan lain pada variabel faktor-faktor yang mendukung dan menghambat fungsi DPRD. Meskipun dari item ini ada hal penting yang dirasa perlu diperhatikan adalah tanggapan sebagian mengenai komunikasi yang efektif dalam pencapaian fungsi DPRD yang lebih baik guna mewujudkan pemerintahan yang baik, bersih dan berwibawa.

\section{KESIMPULAN DAN SARAN}

Dewan Perwakilan Rakyat Daerah (DPRD) sebagai lembaga perwakilan rakyat di daerah mempunyai peran penting dalam tata kelola pemerintahan di daerah. Para anggota DPRD, melalui partai politik, mewakili masyarakat sehingga harus berperan besar dalam mengupayakan demokrasi dan mewujudkan tata pemerintahan yang baik dan efisien di daerahnya. Upaya tersebut bisa dilakukan dengan mengoptimalkan fungsifungsi DPRD yaitu: Legislasi, Penganggaran, dan Pengawasan. Untuk mencapai kinerja yang maksimal dalam pelaksanaan fungsi-fungsi tersebut, perlu dilakukan penguatan terhadap kapasitas DPRD. Berdasarkan dari hasil penelitian yang dilakukan peneliti tentang Fungsi DPRD dalam Mewujudkan good governance, maka dapat disimpulkan bahwa hasil penelitian menyatakan bahwa jawaban atau tanggapan anggota DPRD 
Kota Malang terhadap item-item pertanyaan terkait dengan mekanisme dan prosedur fungsi DPRD dalam mewujudkan good governance dikatakan baik. Tanggapan atau persepsi responden tentang keterkaitan antara alat kelengkapan atau badanbadan dalam pelaksanaan fungsi DPRD Kota Malang adalah baik. Sebagaimana dilihat pada hasil evaluasi kuesioner yang dilakukan oleh peneliti menunjukkan bahwa tingkat persepsi hampir ratarata sangat setuju maupun setuju, hal ini karena responden lebih cenderung pada pimpinan maupun komisi-komisi perlu adanya kerjasama yang efektif. Dan Tingkat tanggapan atau persepsi responden terhadap tentang faktor-faktor yang mendukung dan menghambat fungsi DPRD Kota Malang dalam mewujudkan good governance. Sebagaimana hasil evaluasi kuesioner yang dilakukan oleh peneliti, maka dengan demikian faktor yang mendukung adalah komunikasi yang efektif, kualitas sumberdaya anggota DPRD. Sementara yang menjadi faktor penghambat adalah anggota DPRD yang kurang memperhatikan aspirasi rakyat,

\section{DAFTAR PUSTAKA}

Agustino, Leo, 2008. Dasar-Dasar Kebijakan Publik. Bandung:Alfabeta.

Badan Pusat Statistik, 2011. Kota Malang Dalam Angka

Budiardjo Miriam, 1993. Dasar-Dasar Ilmu Politik.Jakarta : Gramedia

Domai, Tjahjanulin, 2011. Sound Governance. Malang :UB Press.

Dunn, William N, 2000. Analisis Kebijakan Publik. Yogyakarta: UGM Press.

Ekowati, M.R.L, 2009. Perencanaan, Implementasi, dan Evaluasi Kebijakan atau Program (Suatu Kebijakan Teoritis dan Praktis).Surakarta: Pustaka Cakra.

Husaini Usman dan Setiady Akbar, 2009. Metodologi Penelitian Sosial. Jakarta: Bumi Aksara.

Harbani, Pasolong, 2007. Teori Adminisatrasi Publik.Bandung: Alfabeta.

Kusumanegara, Solahuddin, 2009. Model dan Aktor dalam Proses Kebijakan Publik.Yogyakarta : Gava Media.

Mardiasmo, 2002. Otonomi dan Manajemen Keuangan Daerah. Yogyakarta: Andi. perilaku dan sikap anggota DPRD, dan faktor pendidikan maupun pengalaman anggota DPRD $(92 \%)$.

Berdasarkan hasil penelitian tersebut, maka peneliti memberikan saran dan rekomendasi dalam perbaikan kedepan adalah diperlukan adanya peningkatan kinerja DPRD yang diikuti oleh sumberdaya manusia (SDM) yang berkualitas sehingga pencapaian fungsi DPRD akan menjadi lebih baik. Adanya daya tanggap DPRD terhadap aspirasi masyarakat agar terciptanya proses partisipatif yang lebih efektif.Perlu adanya peningkatan kemampuan calon legislatif dari partaipartai politik melalui pengkaderan yang profesional agar kredibilitas calon legislatif dapat memberikan kontribusi kinerja yang lebih baik.Diperlukan adanya kontrol dari Lembaga Swadaya Masyarakat (LSM) maupun stakeholder terkait dengan evaluasi dalam rangka meningkatkan kinerjafungsi DPRD guna mewujudkan good governace.

Miles, Mathew B dan Huberman, A Maichel, 1992. Analisa Data Kualitatif.Jakarta: UI Press.

Moleong, Lexy J, 2007. Metodologi Penelitian Kualitatif.Rosdakarya. Bandung.

Miriam Budiardjo dan Ibrahim Ambong, 1995, Fungsi Legislatif Dalam Sistem Politik Indonesia. Jakarta: RajaGrafindo Persada.

Nasution, 2003. Metode Penelitian Naturalistik Kualitatif.Bandung : Tarsito.

Sadhana, Kridawati, 2011. Realitas Kebijakan Publik. Malang: UM Press.

Sedarmayanti, 2009. Reformasi Administrasi Publik, Reformasi Birokrasi, dan Kepemimpinan Depan (Mewujudkan Pelayanan Prima dan Kepemerintahan yang Baik).Bandung: Refika Aditama.

Sugiyono, 2010. Memahami Penelitian Kualitatif.Bandung : Alfabeta.

Suharto, Edi, 2007. Kebijakan Sosial Sebagai Kebijakan Publik.Bandung : Alfabeta.

Surbakti, Ramlan, 2010. Memahami Ilmu Politik. Jakarta: Grasindo.

Thaib, Dahlan, 2000. DPR Dalam Sistem Ketatanegaraan Indonesia. Yogyakarta: Liberty. 
Widodo, Joko, 2001. Good Governance; Telaah dari Dimensi Akuntabilitas dan Kontrol Birokrasi Pada Era Desentralisasi dan Otonomi Daerah. Surabaya :Insan Cendekia.

2006.Analisis Kebijakan Publik, Konsep dan Aplikasi Analisis Proses Kebijakan Publik.Malang :Bayumedia Publishing.

\section{Peraturan Perundang-Undangan}

Undang-Undang Republik Indonesia Nomor 32 Tahun 2004 Tentang Pemerintahan Daerah.

Peraturan DPRD Kota Malang No. 01 Tahun 2011

Tentang Tata Tertib Dewan Perwakilan Rakyat Daerah Kota Malang. 